\title{
Happy ending in two elderly patients with generalized tetanus
}

\section{İki yașlı jeneralize tetanoz olgusunda mutlu son}

Emine PARLAK ${ }^{1}, \quad$ Ayșe ERTÜRK ${ }^{2}, \quad$ Yasemin SEVGiLi-ÇAĞ ${ }^{3}, \quad$ Zahide KOȘAN ${ }^{1}$

\section{ABSTRACT}

The causative agent of tetanus is Clostridium tetani. The disease can be prevented with vaccination, but mortality and morbidity rates are high. Mortality rates in tetanus range between $25 \%$ and $60 \%$. Prognosis is poor in the presence of advanced age, dirty wounds, generalised cases and a short incubation period. Awareness in society must be increased and immunization programs must be developed. Patients should be observed in intensive care units. Supportive care is very important advenced, as well as medical treatment. This consists of avoidance of early intubation, ventilation, tracheotomy and nosocomial infections. We describe two elderly patients observed in intensive care and discharged with full recovery, even though no post-exposure prophylaxis was administered.

Key Words: Clostridium tetani, immunoprophylaxis, opisthotonus, mechanical ventilation, tetanus

\section{ÖZET}

Clostridium tetani tetanozun etkenidir. Tetanoz așı ile önlenebilen, mortalitesi ve morbiditesi yüksek bir hastalıktır. Tetanozda mortalite \%25-60 arasında değişir. İnkübasyon dönemi kısa olanlarda, kirli yaralanmalarda, ileri yașta, jeneralize olanlarda prognoz kötüdür. Toplumda farkındalık arttırılmalı ve immunizasyon programları geliștirilmelidir. Hastalar gelișmiş yoğun bakım ünitelerinde izlenmelidir. Tıbbi tedavilerin yanı sıra erken entübasyon, ventilasyon, trakeostomi, yeterli beslenme ve nozokomiyal enfeksiyonların önlenmesi gibi destek tedavileri de çok önemlidir. Temas sonrası profilaksi verilmemesine rağmen yoğun bakımda izlenip șifa ile taburcu edilen jenaralize tetanozlu iki yașlı erkek hasta sunulmaktadır.

Anahtar Kelimeler: Clostridium tetani, immunoprofilaksi, opistotonus, mekanik ventilasyon, tetanoz

' Department of Infectious Diseases and Clinical Microbiology, Atatürk University Faculty of Medicine, ERZURUM, TURKEY

${ }^{2}$ Department of Infectious Diseases and Clinical Microbiology, Recep Tayyip Erdogan University Faculty of Medicine, RiZE, TURKEY

${ }^{3}$ Department of Infectious Diseases and Clinical Microbiology, Lütfi Kırdar Training and Research Hospital, ISTANBUL, TURKEY

İletişim/Corresponding Author : Emine PARLAK

Department of Infectious Diseases and Clinical Microbiology, Atatürk University Faculty of Medicine, ERZURUM, TURKEY Geliş Tarihi / Received : 07.04.2015

Tel : +904422310686 E-posta/E-mail : eparlak1@yahoo.com Kabul Tarihi/Accepted : 25.08.2015

DOI ID : 10.5505/TurkHijyen.2015.80388

Parlak E, Ertürk A, Sevgili-Çağ Y. Happy ending in two elderly patients with generalized tetanus. Turk Hij Den Biyol Derg, $2015 ;$ 72(4): 317-22. 


\section{INTRODUCTION}

Clostridium tetani is an anaerobic gram-positive spore-forming bacillus. Its natural habitat is soil (1). Tetanus is a well-defined and well-known disease and a significant cause of mortality. It is not common in industrial countries but represents a health problem in developing ones (2). The disease occurs as a result of injuries with objects that contain the spores (3). The spore produces toxins by passing into a vegetative state in suitable injuries. Tetanospasmin, which is responsible for all clinical symptoms, enters the central nervous system through retrograde axonal transport. Since it is a neurotoxin it binds irreversibly to neurons $(1,3,4)$. It prevents, the release of inhibitory neurotransmitters [gammaaminobutyric acid (GABA) and glycine]. Tonic spasms exhibit sympathetic and parasympathetic effects (3). Response to external stimuli consists of severe and sustained muscle contractions in which agonist and antagonist muscles contract simultaneously (5). The toxin causes rigidity and spasm in muscles. Clinical manifestations of muscle contractions include trismus and opisthotonus. Patients can even be irritated by very minor stimuli. The other toxin, tetanolysin, is responsible for haemolysin and spreading the bacteria. The most common form of the disease is generalised tetanus (3). Acute respiratory failure caused by muscle spasm is a major cause of mortality. It is reported that giving advanced ventilator support in intensive care unit decreased the mortality rate by four fold. (2). In recent years, improvement in the prognosis of tetanus has been observed with the use of intensive care units (6). Diagnosis in our cases was based on patients' history of trauma and clinical features (widespread muscle contractions). Vaccine and tetanus immunoglobulin were administered in the emergency department. This case report evaluates the clinical features, treatment parameters and prognoses of two elderly patients with tetanus.
Case 1: A 70-year-old male patient had received dressing at a cottage hospital due to cuts on the first finger of the right hand. The incubation period was ten days. He refused to go to a public hospital, and prophylaxis was not applied. Ten days later, he was brought to the emergency department with locked jaw in the opisthotonus position. The other symptom was contraction of the legs. He presented with generalised tetanus. Wound debridement was permormed purged with plenty of oxygen water. Relatives were unable to recall his vaccination status. At physical examination, body temperature was $36^{\circ} \mathrm{C}$, pulse $73 / \mathrm{min}$ and arterial blood pressure $95 / 52 \mathrm{mmHg}$. Bilateral lung sounds were coarse. Light reflex and corneal reflex were bilaterally positive, and the pupils were isochoric. The patient was taken to the intensive care unit on the first day of admission. Intravenous antibiotic (metronidazole 4 × $500 \mathrm{mg}$ ) was applied as empiric treatment. It was continued for 10 days. Tetanus immunoglobulin (500 IU), and tetanus vaccine were administered. The patient's general condition was poor. He was unconscious, with a Glasgow Coma Score (GCS) of 3. Resuscitation in the intensive care unit was included in the first day of mechanical ventilation support. Diazepam and morphine were used for patient sedation and muscle contractions. Tracheostomy was performed on the 7th day of admission. Initial laboratory values are shown in Table 1. Creatine kinase level increased to 2232 $\mathrm{IU} / \mathrm{L}$. Pneumonia developed due to intubation in intensive care unit. He remained haemodynamically stable. Hypertension and tachycardia were developed. Cardiovascular stability was established with phentolamine, calcium channel blockers and atropine. Mechanical ventilation was maintained for 16 days. The patient remained under observation in the infectious disease department and intensive care unit for 25 days. Physiotherapy 
was provided and the patient was discharged uneventfully.

Case 2: A 79-year-old male experienced leg pain and weakness 10 days after treading on a nail with his right foot. A few days later, he was admitted to the emergency department with intense sweating, locked jaw and spasms in the legs and back. The incubation period was thirteen days. Relatives stated that he had never been vaccinated. The nail place could not be found. First symptom was significant contraction in the leg. Tetanus vaccine and 500 IU TIG were administered, metronidazole $(3 \times 500$ $\mathrm{mg}$ ) started. It was continued for 10 days. Arterial blood pressure was $150 / 80 \mathrm{mmHg}$, heart rate was 98 beats/min and his Glaskow Coma Scale (GCS) was found to be 15 (G4M6V5). Creatine kinase was elevated, at $1369 \mathrm{IU} / \mathrm{L}$. Progressive contractions were observed, and the patient was intubated in the reanimation unit. Tracheostomy was performed due to severe laryngospasm on the 9th day. Mechanical ventilation was performed for 17 days.

Table 1. Patients' hospitalization laboratory values

\begin{tabular}{lcc}
\hline Parameters & Case 1 & Case 2 \\
\hline AST (IU/L) & 31 & 59 \\
ALT (IU/L) & 16 & 36 \\
CK (IU/L) & 199 & 1355 \\
ALP (IU/L) & 155 & 106 \\
LDH (IU/L) & 411 & 354 \\
Myoglobin $(\mu \mathrm{g} / \mathrm{L})$ & 65.36 & 577.1 \\
WBC $\left(\times 10^{9} / \mathrm{L}\right)$ & 16 & 12.1 \\
CRP $(\mathrm{mg} / \mathrm{L})$ & 69 & 17.2 \\
\hline ESR $(\mathrm{mm} / \mathrm{h})$ & 45 & 67 \\
\hline
\end{tabular}

AST aspartate aminotransferase; ALT alanine aminotransferase; CK creatine phosphokinase; ALP alkaline phosphatase; LDH lactate dehydrogenase; WBC white Blood Cells; CRP: C-reactive protein; ESR erythrocyte sedimentation rate
Pneumonia developed. Piperasilin-tazobactam was started. Diazepam and morphine were used for patient sedation and muscle contractions. Cardiovascular stability was established with phentolamine, calcium channel blockers and atropine. The patient was observed in the infectious diseases unit for 35 days and eventually discharged in a healthy condition.

\section{DISCUSSION}

Tetanus is a preventable disease (2). Diagnosis is based on history and clinical findings $(1,4,6)$. Generalized, localized, cephalic and neonatal forms exist, depending on host factors and site of injury (1). The most common form is generalized tetanus (3). Our two cases presented with the generalised form. The incubation period (IP) is 2-3 weeks (7), with a mean of 15 days. Shortening of this time has a severe impact on prognosis (6). Period of onset (PO) is reported at 1-4 days (7). An IP less than 8 days, a $\mathrm{PO}$ of less than 2 days and presence of generalized form, fever and tachycardia indicate poor prognosis (6). Incubation period exceeded 7 days in our cases. The presence of chronic disease increases tetanusrelated mortality. Our patients had no chronic disease.

The initial finding in patients with the masseter muscle rigidity was trismus (5). This is followed by risus sardonicus, opisthotonus, muscle spasms, abdominal rigidity and severe pain linked with being conscious $(6,7)$.

The annual number of cases worldwide is approximately 1 million (4). Immune globulin levels decrease in advanced age with incomplete vaccination and irregular implementation of the vaccination schedule. The disease is therefore particularly important in patients over $50(4,6)$. Elderly patients constitute the immediate risk group $(1,8)$. One of our patients was 74 years old and the other was 70 . Vaccination is the only 
way of protection the disease can be prevented by active immunization or appropriate care and passive immunization after injury (2). Patients who have received primary vaccination must be given tetanus toxoid once every 10 years. Our patients' vaccination status was either not known or no vaccination had been performed. No wound care or prophylaxis had been performed after injury. The wounds were cleaned and debridement was performed.

Risk factors include surgical procedures, dental treatment, contaminated wounds, burns and intramuscular and intravenous drug injections (1). Mild to moderate injuries such as wounds caused by stones, nails, rusty tins and presence of wood pieces have been reported as the cause of the disease (6). In our two cases, mild wounds involving nail and simple hand cuts were involved. Care should be taken even with mild injuries. The unapplied prophlaxy to two patients is a sign of lack of education.

The aims in tetanus treatment are to reduce the levels of toxins from the circulation, to achieve hemodynamic stability and to control muscle contraction. Human immunoglobulin (TIG) in 5006000 units should be administered immediately. There is no consensus in the literature in terms of dosage (8). Both of our patients were vaccinated and treated with TIG on admission. Neuromuscular blocker agents (diazepam, and propofol) were used in order to control the spasms. Alternatively, the use of propofol, baclofen, barbiturate, dantrolen and vecuronium has also been proposed for persistent spasms in generalised tetanus. Cardiovascular stability was established with phentolamine, calcium channel blockers and atropine. During medical and antimicrobial treatment, empiric metronidazole $3 \times 500 \mathrm{mg}$ was administered for 10 days. Metronidazole is reported to be a suitable choice in view of its low mortality rates compared with penicillin. As a GABA antagonist, penicillin is not an appropriate choice regarding its antagonistic actions to benzodiazepines. Clindamycin, tetracycline and erythromycin are acceptable alternatives $(1,7)$.

The most important problems in generalised tetanus are laryngospasm and respiratory retention involving asphyxia (5, 7). Such patients are generally attached to mechanic ventilators (7). Patients may develop respiratory, cardiac and infectious problems (10). The most common complication is ventilator-associated pneumonia, followed by catheter infections, urinary system infections, deep vein thrombosis, contracture, tachycardia, hypotension, hypertension and cardiac dysrhythmias including autonomic instability, reddening on the face, long bone fractures, paralytic ileus, pressure sores, urinary retention, malnutrition, stress ulcers, coma, nerve palsies and sweating $(4,7,8)$. Intubation and mechanical ventilation were performed in our cases. Nosocomial pneumonia developed in both patients in concomitantly. Appropriate antibiotherapies were administered.

Patients should be monitored in well-equipped intensive care units (7). Medication and supportive treatment can thus be given together. This has a positive effect on prognosis. The effect of the intensive care unit treatment was manifested as a decrease in mortality $(3,6,8,9)$. Intensive care support and treatment are very important in generalized tetanus. Our patients were treated in intensive care in the early stage and were observed in intensive care unit along with their mechanical ventilation requirements. Antibiotics and other drugs were arranged in a multidisciplinary manner, and one received physiotherapy. No mortality occurred. Adequate nutrition was provided, and ulcer and heparin prophylaxis were administered.

Definitive diagnosis should be performed for strychnine poisoning, still person syndrome, 
hypocalcemic tetany, attacks, meningitis, dystonic reactions resulting from neuroleptic medicines, neuroleptic malign syndrome, peritonsillar abscess, diphtheria, mumps and mandibular fracture (1).

Tetanus is a disease with a high mortality rate despite modern intensive care unit treatment options. Mortality rate is $17 \%$, and increases to more than $20 \%$ in patients over 60 years of age $(1,7)$. In some studies, however, mortality rates of $50 \%$ have been reported in newborn and elderly patients $(10,11)$. Reported causes of mortality include sepsis of pulmonary origin, cardiac arrest, acute heart failure and hemodynamic instability (7). Nosocomial infections are also an important cause of mortality (6). Pneumonia attack occurred in both our cases. However, nosocomial infection did not resulted in mortality.
In conclusion, without treatment, tetanus can be fatal. A significant proportion of these deaths can be prevented by safe, inexpensive vaccinations. Patients need long-term general support measures. Advanced intensive care unit treatment is essential. In our cases observation in intensive care reduced mortality and permitted hemodynamic and mechanical ventilation support. Proper management is essential in avoiding nosocomial complications. Patients can be lost due to intensive care infections and respiratory problems. As the disease is more severe at advanced ages, booster shots and vaccination should be considered after the age of 40 . Immunoprophylaxis and wound care after injury must be performed properly. The disease should be managed in a multidisciplinary manner regarding its high mortality.

\section{CONFLICT OF INTEREST}

The authors declare no conflicts of interest.

\section{REFERENCES}

1. Srigley JA, Haider S, Johnstone J. A lethal case of generalized tetanus. CMAJ, 2011; 183(9): 1045-8.

2. Trujillo MH, Castillo A, Espano J, Manzo A, Zerpa R. Impact of intensive care management on the prognosis of tetanus, analysis of 641 cases. Chest, 1987; 92(1): 63-5.

3. Aydın K, Köksal I, Volkan S, Çaylan R, Öksüz R, Kardeș BA, Köksal $H$. Tetanoz vakalarının immünizasyon tedavi ve prognozlarının değerlendirilmesi. FLORA, 1996; 1: 66-9.

4. Anuradha S. Tetanus in Adults - A Continuing Problem: An analysis of 217 patients over 3 years from delhi, india, with special emphasis on predictors of mortality. Med J Malaysia, 2006; 61(1): 7-14.
5. Geyik M F, Üstün C, Çelen M K, Eraydın H, Hoșoğlu $\mathrm{S}$, Ayaz C. Jeneralize tetanozda kasılmalar için propofol kullanımı: Olgu sunum. İnfek Derg, 2006; 20(3): 203-5.

6. Kömür S. Tetanoz: Altı olgunun değerlendirilmesi Mediterr J Infect Microb Antimicrob, 2013; 2: 7 .

7. Salman C, Sekban N, Döșemeci L, Cengiz M, Yılmaz M, Ramazanoğlu A. Yoğun bakımımızda tetanoz: On yedi hastada tedavi, komplikasyonlar ve mortalitenin değerlendirilmesi. Türk Anest Rean Dergisi, 2007; 35(3): 200-8.

8. Loeffler C, Mols G, Hecksteden K, Pfeiffer J, Ridder GJ. A minor wound with a fatal course. BMJ Case Rep, 2011 doi: 10.1136/bcr.04.2011.4100. 
9. Demirel İ, Üstün S, Üstün C. Mekanik ventilasyona gereksinim gösteren tetanoz olgusu. Firat Tıp Derg, 2012; 17(4): 69-71.

10. Kuzucuoğlu T, ital i, Alatlı i. Ciddi bir tetanoz olgusunun yoğun bakımda takip ve tedavisi. J Kartal TR, 2011; 22(1): 45-8.
11. Loeffler C, Mols G, Hecksteden K, Pfeiffer J, Ridder GJ. A minor wound with a fatal course. BMJ Case Reports, 2011; doi:10.1136/bcr.04.2011.4100. 